\title{
CYCLIC AMP AND THE TRIGGERING OF THE DECIDUAL REACTION
}

\author{
F. LEROY,* J. VANSANDE, G. SHETGEN AND D. BRASSEUR
}

Laboratory of Experimental Gynaecology, St Pierre Hospital, and Laboratory of Nuclear Medicine, Free University of Brussels, Belgium

Despite the many efforts to unravel the mechanism of decidual induction, the only coherent attempt so far has been put forward by Shelesnyak and his associates (Shelesnyak, 1957), emphasizing the possible rôle of histamine. Although this theory has been challenged for various reasons (De Feo, 1967; Finn, 1971), when one examines the available data, it seems difficult to escape the conclusion that histamine must indeed have something to do with some early step of the decidual reaction.

On the other hand, there is now increasing evidence that, as is the case with other biogenic amines, the action of histamine would be mediated through cyclic AMP (see Table 1). Therefore it was thought that cyclic AMP might be involved in the onset of decidualization.

In order to demonstrate that a substance acts through cyclic AMP, four criteria have been suggested (Pastan \& Perlman, 1971): cyclic AMP or a suitable analogue should mimic the substance's action; methylxanthines should mimic or potentiate this action; the substance should increase cyclic AMP levels in the target tissue; it should increase adenylcyclase activity in target tissue extracts.

The first two of these criteria have been examined, using spayed mice prepared with hormonal steroids in such a way as to provide maximal uterine sensitivity to decidual induction. Text-figure 1 outlines the schedule of this procedure, which was taken from the work of Finn (1971).

Eight to ten $\mathrm{hr}$ after the sensitizing dose of oestradiol-17 $\beta$ (10 $\mathrm{ng})$, groups of ten animals (or more) received a $5 \mathrm{mg}$ intraperitoneal dose of one of the following compounds: adenosine-5' non-cyclic monophosphate (controls); adenosine$3^{\prime}, 5^{\prime}$ cyclic monophosphate; $\mathrm{N}^{6}, \mathrm{O}^{2}$-dibutyryl adenosine- $3^{\prime}, 5^{\prime}$ cyclic monophosphate. This procedure was repeated with increasing doses of the nucleotides up to $15 \mathrm{mg}$. In two out of six experiments, the cyclic AMP and its dibutyryl derivative were given together with $2 \mathrm{mg}$ theophylline. The animals were killed after 4 days during which they received adequate hormonal support for decidual development (Text-fig. 1).

Table 2 presents the only experiment of this type which gave some positive, although not conclusive, results. Indeed with less than a $15 \mathrm{mg}$ dose, we could only observe an occasional small deciduoma in never more than one animal per group. Since this would sometimes occur in controls as well, there were no meaningful differences between the different experimental groups. It will be noticed, however, that $15 \mathrm{mg}$ of dibutyryl-cyclic AMP given with theophylline * 'Chargé de Recherches' at the Belgian F.N.R.S. 
Table 1. Histamine and cyclic AMP

\begin{tabular}{l|c|c|c}
\hline \multicolumn{1}{c|}{ Species } & \multicolumn{1}{c|}{ Tissue } & Histamine effect on c-AMP levels & \multicolumn{1}{c}{ Authors } \\
\hline $\begin{array}{l}\text { Rabbit } \\
\text { Guinea-pig }\end{array}$ & $\begin{array}{l}\text { Cortex } \\
\text { Gerebellum }\end{array}$ & $\begin{array}{l}\text { 5- to 10-fold elevation (or more) } \\
\text { (potentiated by methylxanthines } \\
\text { inhibited by antihistamines) }\end{array}$ & $\begin{array}{l}\text { Kakiuchi \& Rall (1968) } \\
\text { Shimizu, Creveling \& } \\
\text { Daly (1970) }\end{array}$ \\
\hline $\begin{array}{l}\text { Guinea-pig } \\
\text { Amphibian }\end{array}$ & $\begin{array}{l}\text { Gastric mucosa } \\
\text { (gastric juice) }\end{array}$ & $\begin{array}{l}\text { 4-fold elevation paralleled by HCl } \\
\text { secretion increase (potentiated by } \\
\text { methylxanthines) }\end{array}$ & $\begin{array}{l}\text { Perrier \& Laster (1970) } \\
\text { Nakajima, Hirschowitz \& } \\
\text { Sachs (1971) } \\
\text { Bieck (1972) }\end{array}$ \\
$\begin{array}{l}\text { Man } \\
\begin{array}{l}\text { Guinea-pig } \\
\text { Man }\end{array}\end{array}$ & Heart muscle & $\begin{array}{l}\text { 3-fold elevation concomitant with } \\
\text { positive inotropic effect (inhibited } \\
\text { by antihistamines) }\end{array}$ & $\begin{array}{l}\text { Klein \& Levey (1971) } \\
\text { Kukovetz \& Pöch (1972) }\end{array}$ \\
\hline $\begin{array}{l}\text { Man } \\
\text { (allergic) }\end{array}$ & Leucocytes & $\begin{array}{l}\text { 100-fold increase concomitant with } \\
\text { inhibition of intracellular anti- } \\
\text { genic histamine release (not } \\
\text { potentiated by methylxanthines) }\end{array}$ & $\begin{array}{c}\text { Bourne, Melmon \& } \\
\text { Lichtenstein (1971) }\end{array}$ \\
\hline
\end{tabular}

(c)

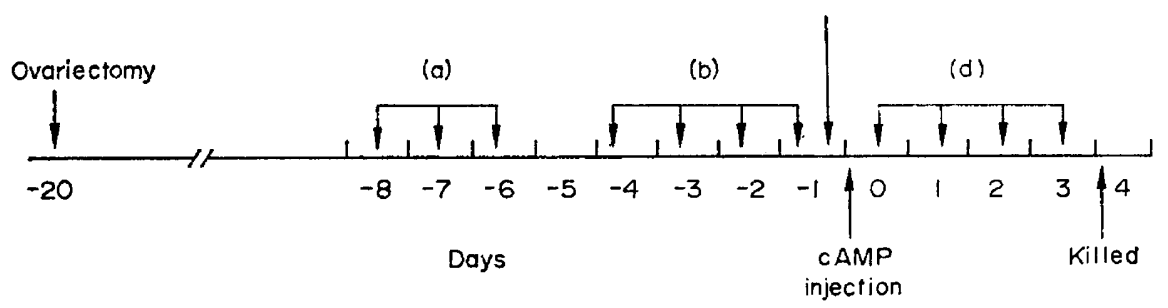

TEXT-FIG. 1. Hormonal treatment of spayed mice to provide maximal sensitivity to decidual induction attempted by exogenous cyclic AMP injections. (a) $0 \cdot 1 \mu \mathrm{g}$ oestradiol17 $\beta /$ day; (b) $1 \mathrm{mg}$ progesterone/day; (c) $10 \mathrm{ng}$ oestradiol-17 $\beta$; (d) $400 \mu \mathrm{g}$ progesterone plus $40 \mathrm{ng}$ oestradiol-17 $\beta /$ day.

Table 2. Decidual induction by exogenous cyclic AMP

\begin{tabular}{l|c|c}
\hline \multicolumn{1}{c|}{ Treatment groups } & $\begin{array}{c}\text { No. of } \\
\text { animals } \\
\text { surviving }\end{array}$ & $\begin{array}{c}\text { No. of } \\
\text { decidualized } \\
\text { uteri* }\end{array}$ \\
\hline 1. $15 \mathrm{mg}$ non-cyclic AMP & 17 & 0 \\
2. $2 \mathrm{mg}$ theophylline & 10 & 2 \\
3. $2 \mathrm{mg}$ theophylline $+15 \mathrm{mg}$ cAMP & 9 & 3 \\
4. $2 \mathrm{mg}$ theophylline+15 mg dibutyryl cAMP & $4 \dagger$ & 3 \\
\hline
\end{tabular}

The compounds were administered by intraperitoneal injection.

* At least one macroscopic deciduoma per uterus.

$\dagger$ Lethality was $60 \%$.

Statistical significance of differences: Group 1 versus Group 2, non-significant;

Group 1 versus Group 3, $P=0.06$; Group 1 versus Group $4, P=0.017$. 
is capable of eliciting a significant number of deciduomata when compared with controls, but it is also clear that this high dose induces quite a high mortality. With the same amount of cyclic AMP, the difference from controls is close to statistical significance; the animals in this case were also severely ill but did not die.

These results do not mean, of course, that exogenous cyclic AMP or dibutyryl cyclic AMP are capable of inducing deciduomata by acting directly on the uterus, since it is only too obvious that under such conditions they may intervene at other levels.

As the next step, the nucleotides or theophylline were injected directly into the uterine cavity of spayed animals placed under similar hormonal conditions, although this does, of course, give rise to the possibility of direct trauma to the uterus. In order to minimize the possibility of non-specific decidual induction, the injections were given under sterile conditions in a volume of $0.01 \mathrm{ml}$, which would not dilate the uterine lumen. Four experiments of this type were

(c)

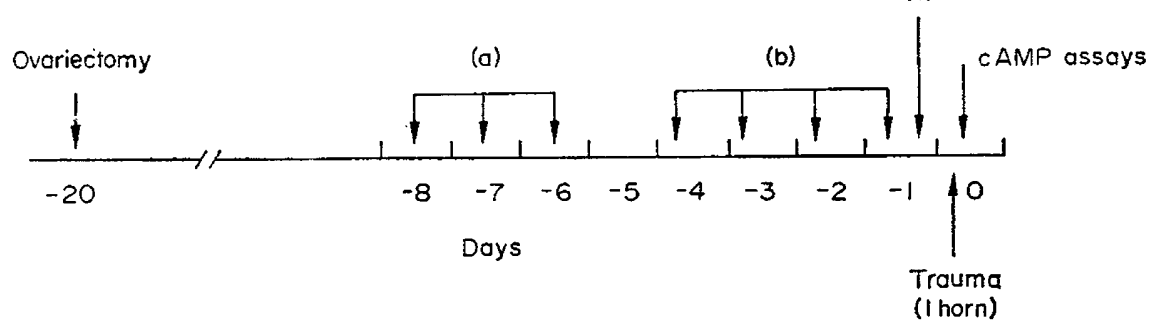

TEXT-FIG. 2. Hormonal treatment of ovariectomized rats submitted to traumatic decidualization in view of uterine cyclic AMP assays. (a) $0.5 \mu \mathrm{g}$ oestradiol-17 $\beta /$ day; (b) $5 \mathrm{mg}$ progesterone/day; (c) $0.1 \mu \mathrm{g}$ oestradiol-17 $\beta$.

performed, using groups of five to ten animals and with doses of nucleotides varying from 0.05 to $0.5 \mathrm{mg}$ per uterine horn. In each animal the contralateral horn was injected with an equal dose of non-cyclic AMP as a control. In these experiments we never observed anything more than several small deciduomata at the injection sites in the control and experimental horns. These were obviously due to direct trauma.

From these investigations using the exogenous approach, it is clear that the direct involvement of cyclic AMP in the onset of the decidual reaction appears at least very doubtful if not excluded.

According to the above-mentioned criteria it was also necessary to investigate whether at the beginning of decidualization there is any modification of cyclic AMP levels in the uterus. This was done in ovariectomized rats which were sensitized to decidual induction by an appropriate hormonal treatment as given in Text-fig. 2. In each animal one horn was traumatized at a proper time by endo-uterine longitudinal scratching, while the other was left intact as a control. The uteri of groups of five or six animals were then taken out at different times after this trauma and each horn was divided transversely in order to assay cyclic AMP in one half and DNA in the other. Cyclic AMP content was 
determined by the competitive protein-binding radioassay described by Gilman (1970) and DNA was estimated by the diphenylamine colorimetric method (Burton, 1956).

There was no significant difference in DNA concentration between the uterine horns. The level of cyclic AMP expressed as pmol/100 $\mu \mathrm{g}$ of DNA was established for each horn and compared between experimental and control horns, taking advantage of the fact that each animal provides its own internal control.

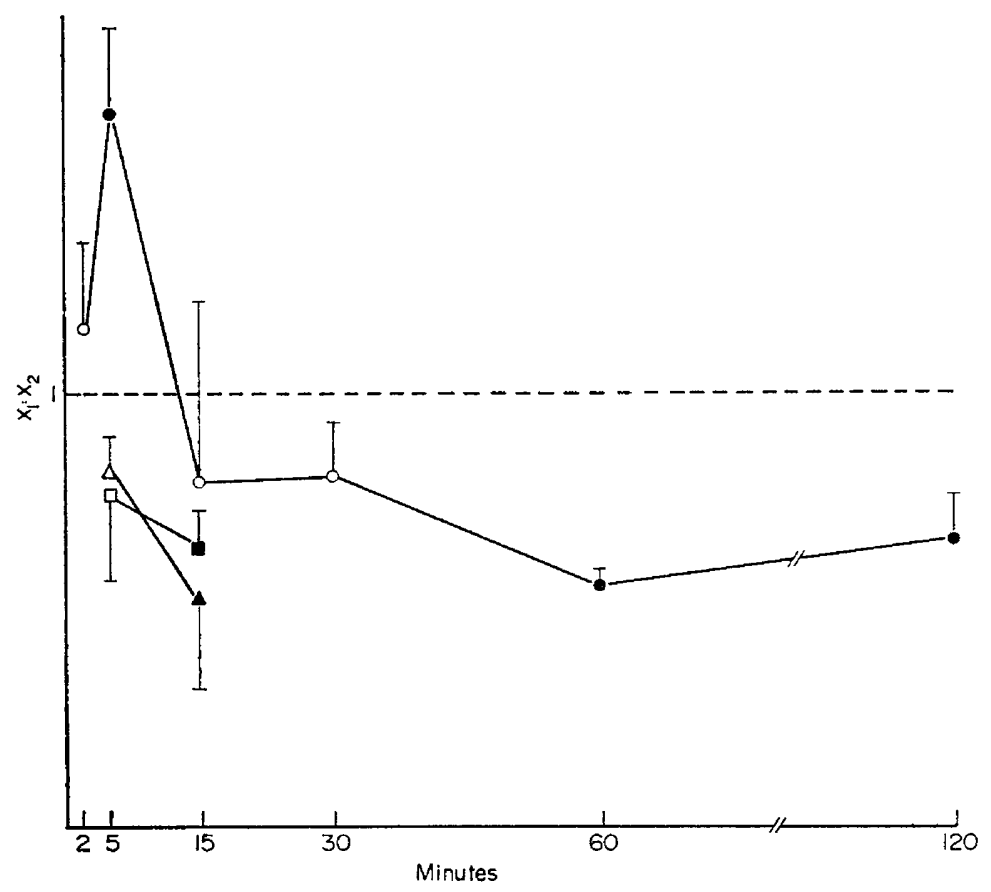

TEXT-FIG. 3. Time course of cyclic AMP levels after trauma in scratched and intact uterine horns in the rat. $O$, animals prepared according to the schedule shown in Text-fig. 2; $\square$, spayed animals without hormonal treatment; $\Delta$, animals treated with $5 \mathrm{mg}$ progesterone for 2 days; solid symbols, $\mathrm{X}_{1}: \mathrm{X}_{2}$ significantly different from 1 .

$$
\mathrm{X}_{1}: \mathrm{X}_{2}=\frac{(\mathrm{pmol} \text { cAMP) } / 100 \mu \mathrm{g} \text { DNA in traumatized horn }}{(\text { pmol cAMP) } / 100 \mu \mathrm{g} \text { DNA in intact horn }}
$$

In Text-fig. 3, mean values of the cyclic AMP concentration ratio $\left(\mathrm{X}_{1}: \mathrm{X}_{2}\right)$ between both horns have been plotted against the time elapsed after trauma. It can be seen that there is a rise of this parameter up to 1.6 at $5 \mathrm{~min}$, after which it falls significantly to low levels until at least $2 \mathrm{hr}$ after decidual induction. It was of course necessary to determine whether this pattern is specific to the hormonal climate providing uterine sensitivity, so the same assays were performed under identical conditions in groups of animals which had received $5 \mathrm{mg}$ progesterone for 2 days or had had no hormonal treatment. The values of $\mathrm{X}_{1}: \mathrm{X}_{2}$ obtained in these cases $5 \mathrm{~min}$ after trauma were not significantly different from 1, whereas after $15 \mathrm{~min}$ they had dropped significantly (Text-fig. 3). 
It thus seems reasonable to assume that the experimental curve is probably specific to the hormonal climate of decidualization.

We would certainly not dare to conclude from this experiment that cyclic AMP plays a prominent rôle in the onset of the decidual reaction. Indeed, in most processes where it has been shown to be involved the variations of cyclic AMP levels are much greater than those we have observed. However, one can perhaps argue that as decidualization is known to start at small areas in the endometrium (Finn, 1971), one cannot expect to detect an important overall rise or decrease of cyclic AMP levels in the whole uterus if this nucleotide is involved.

The question of a possible positive or negative rôle for cyclic AMP in the decidual reaction therefore remains open for further experimentation.

\section{REFERENGES}

BIECK, P. R. (1972) Role of cyclic AMP in the regulation of gastric secretion in dogs and human. Adv. cyclic Nucleotides Res. 1, 149.

Bourne, H. R., Melmon, K. L. \& Lichtenstein, L. M. (1971) Histamine augments leucocyte adenosine $3^{\prime}, 5^{\prime}$-monophosphate and blocks antigenic histamine release. Science, $\mathcal{N} . Y .173,743$.

Burton, K. (1956) A study of the conditions and mechanism of the diphenylamine reaction for the colorimetric estimation of DNA. Biochem. 7. 62, 315.

De Feo, V. J. (1967) Decidualization. In Cellular Biology of the Uterus, pp. 192-291. Ed. R. M. Wynn. North-Holland Publ. Co., Amsterdam.

Fin, G. A. (1971) The biology of decidual cells. Adv. reprod. Physiol. 5, 1.

Gilman, A. G. (1970) A protein binding assay for adenosine $3^{\prime}, 5^{\prime}$-cyclic monophosphate. Proc. natn. Acad. Sci. U.S.A. 67, 305.

Kakiuchi, S. \& Rall, T. W. (1968) Studies on adenosine 3',5'-phosphate in rabbit cerebral cortex. Molec. Pharmac. 4, 379.

KLEIN, I. \& LEVEY, G. S. (1971) Activation of myocardial adenyl cyclase by histamine in guinea pig, cat and human heart. F. clin. Invest. 50, 1012.

Kuxovetz, W. R. \& Pöch, G. (1972) The positive inotropic effect of cyclic AMP. Adv. cyclic Nucleotides Res. 1, 261.

Nakajima, S., Hirschowitz, B. I. \& Sachs, G. (1971) Studies on adenylcyclase in Necturus gastric mucosa. Archs Biochem. Biophys. 143, 123.

Pastan, I. \& Perlman, R. L. (1971) Cyclic AMP in metabolism. Nature, New Biol, 229, 5.

Perrier, C. V. \& LAster, L. (1970) Adenyl cyclase activity of guinea pig gastric mucosa: stimulation by histamine and prostaglandins. F. clin. Invest. 49, 73a.

SHELESNYAK, M. G. (1957) Some experimental studies on the mechanism of ova-implantation in the rat. Recent Prog. Horm. Res. 13, 229.

Shimizu, H., Greveling, G. R. \& Daly, J. W. (1970) The effect of histamine and other compounds on the formation of adenosine 3',5'monophosphate in slices from cerebral cortex. F. Neurochem. 17,441 . 